\title{
Legislative Responses to Wrongful Conviction: Do partisan principals and advocacy efforts influence state-level criminal justice policy?
}

\author{
Stephanie L. Kent \\ Cleveland State University, s.l.kent59@csuohio.edu \\ Jason T. Carmichael
}

Follow this and additional works at: https://engagedscholarship.csuohio.edu/clcas_facpub

How does access to this work benefit you? Let us know!

\section{Publisher's Statement}

Copyright @ 2015 Elsevier Inc.: https://www.sciencedirect.com/science/article/pii/ S0049089X15000216

\section{Recommended Citation}

Kent, Stephanie L. and Carmichael, Jason T., "Legislative Responses to Wrongful Conviction: Do partisan principals and advocacy efforts influence state-level criminal justice policy?" (2015). Criminology, Anthropology, \& Sociology Faculty Publications. 3.

https://engagedscholarship.csuohio.edu/clcas_facpub/3

This Article is brought to you for free and open access by the Criminology, Anthropology, \& Sociology Department at EngagedScholarship@CSU. It has been accepted for inclusion in Criminology, Anthropology, \& Sociology Faculty Publications by an authorized administrator of EngagedScholarship@CSU. For more information, please contact library.es@csuohio.edu. 


\title{
Legislative responses to wrongful conviction: Do partisan principals and advocacy efforts influence state-level criminal justice policy?
}

\author{
Stephanie L. Kent, Jason T. Carmichael
}

Why do states differ in their commitment to identifying, preventing, and ameliorating wrongful criminal convictions? Over the last several decades there has been a growing public concern over the possibility that individuals could be convicted and sanctioned for crimes they did not commit (Zalman et al., 2012) and scholarly attention has followed (c.f. Garrett, 2011; Martin, 2001; Huff et al., 1996). This heightened concern has led to the identification of specific public policies and practices that appear to significantly contribute to system fallibility (Free and Ruesink, 2012). In response, advocates for change and legal scholars have advanced a series of legislative changes that can substantially reduce the likelihood of convicting individuals for crimes they did not commit. With these available guidelines, individual states have the ability to institute statutory changes that can begin to reduce wrongful convictions, and also compensate those who are victims of such miscarriages of justice. Such legislative changes are necessary because it is increasingly clear that wrongful convictions do not simply result from chance error by individuals in particular courtrooms, but instead reflect systemic errors (Zalman et al., 2012).

Punishing the innocent clearly violates the conscience of an advanced society. But if these errors are inherently part of our system of justice, there are profound legal implications as well. Indications of flaws in our courts not only erode public trust in the legal system but also reveal, as Martin (2001) so aptly points out, that "a double failure" has occurred such that "not only is an innocent person wronged by the conviction but the guilty person is thereby allowed to go free" (pg. 847). Given such serious consequences, it is not surprising that the media, scholars, advocacy groups and policymakers have been working for many years to expose such cases and to promote criminal justice reforms that make wrongful conviction less likely. Despite such widespread efforts, there are still important aspects of this process that remain understudied. In particular, Leo 
(2005), in his review and commentary on the state of the study of wrongful convictions notes that while lawyers have often written on the topic, social scientists have only just begun to empirically study miscarriages of justice and must continue to focus on organizational, macro-level factors that affect criminal justice practices. He concludes: "Criminologists need to better understand sociologically how the various legal actors promote certain perspectives and ideologies about justice and how, in fact, they deliver justice." (216). Leading scholars of wrongful convictions agree that altering policy is a useful avenue for reform (Forst, 2004; Garrett, 2011; Gould, 2008) but it is clear that states vary widely in their willingness to effect legislative change aimed at reducing wrongful convictions. Why is it that some states readily adopt the policy reforms while others appear reluctant to do so? To date, no study has attempted to systematically identify structural conditions within states that make the adoption of public policy designed to reduce the risk of wrongful convictions more or less likely. We begin to fill the need for such research by borrowing theoretically derived explanations taken from previous scholarship on legislative change to isolate the contextual factors that influence the adoption of criminal justice policies related to wrongful convictions across U.S. states. Before we develop these theoretical accounts we first provide a brief overview of wrongful convictions in the U.S. criminal justice system.

\section{Brief overview of wrongful convictions in the United States}

Though Borchard (1932) qualitatively studied the incidence of system errors that led to wrongful convictions as early as the 1930s, the development of DNA technology in the 1980s and the mistakes revealed by testing convicted criminals' DNA evidence to prove their innocence was partly responsible for renewed scholarly interest in wrongful convictions. Dozens of studies have since been published on this issue, many of which attempt to document the frequency of wrongful conviction (e.g. Risinger, 2007 reports that up to $5 \%$ of criminal cases have factual errors in them) or the reasons for these mistakes such as eyewitness error (e.g. Wells and Olson, 2003), false confessions (Kassin et al., 2010; Garrett, 2011) or professional errors by members of the criminal justice workgroup (McMahon, 1995). Many of these studies, however, focus on system errors in capital punishment cases even though nearly two thirds of wrongful convictions stem from noncapital violent crimes such as rape or assault (Ramsey and Frank, 2007).

Revelations of criminal justice errors reported in the media increased public awareness about the possibility of convicting an innocent person (Baumgartner et al., 2008). Consider for example, Anthony Porter, a man whose lawyer fell asleep during trial, who was convicted and sentenced to death due to faulty eyewitness testimony obtained through police coercion, who was luckily exonerated just days before his execution due to a pro-bono investigation that revealed the actual perpetrator. Stories like this one made news headlines and were the subject of documentaries that increase public awareness of these miscarriages of justice.

The fallout from these types of mistakes is immeasurable. The immediate actors in the criminal incident, (the offenders, victims, and their families) are burdened with the enormous personal and financial costs of a wrongful conviction; however, there is also an unbearable social price of these mistakes. The public's confidence in the criminal justice system is shaken as they grapple with both the public safety concern that the actual perpetrator is among them, as well as the disappointment in the system's concern with individual justice.

\subsection{Incidence of wrongful convictions}

While it is virtually impossible to know precisely how many innocent people are behind bars, a number of studies have attempted to gauge the frequency of wrongful conviction with estimates ranging rather widely depending on the methodology employed to produce the estimate. Risinger (2007), for instance, examined capital rape-murder cases between 1982 and 1989 and, using DNA evidence, concluded that the innocence rate was at least $3.3 \%$ and could be as high as $5 \%$. If we extrapolate Risinger's findings to all felony convictions, there could be as many as 100,000 of the over 2 million currently behind bars that are innocent of the crime. Another study conducted by Ramsey and Frank (2007), used a survey to gauge how frequently police, prosecutors, defense attorneys and judges believe wrongful felony convictions occur in their own jurisdictions. They found that these criminal justice practitioners estimated that between $.5 \%$ to $1 \%$ of all felony cases convicted the wrong person (Ramsey and Frank, 2007), which translates into about 20,000 innocent individuals among the over $2,000,000$ serving time behind bars. Beyond pointing to an estimate of the incidence of wrongful conviction, the survey also revealed that these professionals believe that even these rather low figures represent unacceptable error rates and predict that policies intended to reduce them would be helpful and accepted among their peers. Thus it appears that criminal justice professionals are aware of the problem of wrongful convictions and recognize the importance of addressing and reducing them through changes in public policy. Action on this front, however, requires legislative change to remedy the system errors that make wrongful conviction more frequent.

\subsection{Changes in public policy}

In an effort to make wrongful convictions less likely, the U.S. Congress took a stand on the issue by passing the Innocence Protection Act as part of the Justice for All Act (2004). This act granted federal inmates the right to petition to use modern DNA testing to fight their conviction, but also provided financial incentives for states that adopt similar legislation. Because 
each state controls its own criminal justice process and procedures that create or remedy the problem of wrongful convictions, there is considerable variation in the laws that states have adopted to limit the incidence of wrongful conviction over the past decade. This variation creates a situation whereby innocent people accused of crimes may be more or less likely to be convicted depending on the state in which the case is disposed. But why have some states instituted laws aimed at reducing these errors while others have largely avoided this issue? To date, the extant literature, with a couple of exceptions we discuss below, has not addressed this question. That said, extensive scholarship in political sociology points to important factors related to legislative change in other areas. In particular, scholars have suggested that interest group advocacy and aspects of the political or social climate are critically important factors predicting the types of laws that are instituted to redress social wrongs (c.f. Owens and Griffiths, 2012). Despite the importance of such environmental factors, the few studies that have investigated state differences in laws related to wrongful convictions failed to consider either the state level political context or advocacy efforts. To rectify this oversight in the extant literature, we pay particular attention in our analyses to differences in both the political climate and extent of interest group advocacy within each state to see if they can improve our understanding of legislative change related to wrongful convictions.

\subsection{Sources of wrongful conviction and legislation designed to reduce the risk}

Perhaps the most telling approach to understanding the source(s) of wrongful convictions is an examination of known cases to see where flaws originate. According to the Innocence Project's documentation of wrongful conviction cases, the retesting of DNA evidence has helped exonerate over 300 factually innocent individuals (www.innocenceproject.org). An inspection of these cases shows that there are common factors that contribute to wrongful convictions, many of which could be reduced with minor modifications to the relevant statutes. ${ }^{1}$ Scholars have long argued that the leading factor associated with wrongful convictions is eyewitness misidentification (Collins and Jarvis, 2009). In fact, studies have shown that anywhere from 77 to 84 percent of wrongful convictions were due to eyewitness error (Huff et al., 1996; Scheck et al., 2000; Garrett, 2011). This type of error is more likely when potentially biased methods are used in the identification of suspects or when police officers' threaten or badger witnesses during interrogations. For example, crime victims or witnesses often identify perpetrators using a "show-up" procedure in which the suspect is brought before the victim/witness and asked if $s($ he $)$ is the offender. The show-up is the most unreliable identification procedure because, unlike an in-person or photo lineup, there is no way to exclude the suspect, thus increasing the chances of misidentification (see Cicchini and Easton, 2010). Advocacy groups like the Innocence Project have lobbied to modify state legislation to reduce the risks of eyewitness errors. In fact, their model legislation to reduce wrongful convictions includes several changes specifically addressing eyewitness procedures. First among these suggested changes are laws prohibiting the use of the show-up procedure.

A separate, yet related issue has to do with false or coerced confessions. Scholarship has shown that false confessions have led to a number of wrongful convictions. Scheck et al. (2000)'s data on exonerated individuals suggests that false or coerced confessions were the primary grounds for conviction in about $25 \%$ of the first 62 post-conviction DNA exonerations, and Garrett (2011) finds that $16 \%$ of the first 250 exonerees confessed to crimes they did not commit, corroborating its role as one of the most common causes of wrongful convictions (Kassin et al., 2010). To reduce the possibility of false confession (especially, those resulting from police coercion during interrogation), advocacy groups have suggested statutory modifications mandating the recording of police interrogations. A number of states have adopted such changes in an effort to reduce the potential for wrongful convictions. In fact, 20 states and the District of Columbia have instituted laws that mandate recorded interrogations. ${ }^{2}$ Why have the majority of states failed to adopt such a measure?

Another common factor leading to wrongful convictions is the mishandling of scientific evidence. Though Collins and Jarvis (2009) dispel the myth that these cases stem from forensic science misconduct, there are other more widespread issues regarding the storage and retaining of DNA evidence. For example, one of the main impediments to the right to use DNA testing is the destruction of evidence such as rape kits, by criminal justice agencies. Former prosecutor and law professor Cynthia Jones asserts that, "While innocence protection statutes have advanced the efforts of prisoners to utilize DNA testing to establish actual innocence, the vast majority of these statutes do not mandate that the government preserve the biological evidence needed for DNA testing. Thus, the right to post-conviction DNA testing created by the overwhelming majority of innocence protection statutes is purely illusory." (2005: 1241). In fact, the Innocence Project reports that evidence has been lost or destroyed in roughly $75 \%$ of the cases they are involved with. In some cases, biological evidence that was lost or meant to be discarded was then found by chance in courthouse basements, prosecutor's closets and even in a garbage dumpster and used to exonerate inmates (Jones, 2005). To avoid such situations, the Innocence Project has advocated for mandatory DNA preservation. While a great deal of legislative change has taken place in this area, it is clear that some states are unwilling to mandate DNA preservation. Data from the Innocence Project archives shows that while each U.S. state has modified relevant statutes to allow for the use of DNA evidence in criminal trials, nearly 20 states still do not require that this evidence be preserved.

\footnotetext{
${ }^{1}$ We acknowledge that some important sources of wrongful convictions are less amenable to legislative efforts (e.g. adequate compensation of lawyers or control of prosecutorial misconduct), however, we focus on those identified by the Innocence Project as having the greatest potential for change through legislative reform.

${ }_{2}^{2}$ Data for state reforms come from the Innocence Project's "Reforms by State" at http://www.innocenceproject.org/news/LawView.php.
} 
Finally, in order to ameliorate mistakes that are made in spite of these advances, 29 states and the District of Columbia have instituted laws that ensure monetary compensation in the event of a wrongful conviction. Even if this is largely a symbolic gesture on the part of the state, ensuring monetary compensation for those who are wrongfully convicted of a crime sends a message to both the public and criminal justice practitioners that resources from public coffers are at stake if the system errs. This potential financial penalty may make criminal justice officials work harder in their day-to-day practices to reduce the chance of a wrongful conviction.

\subsection{Summary}

Convicting a person for a crime they did not commit has substantial consequences beyond those directly involved. Wrongful convictions have societal implications because they degrade the reputation of the criminal justice system and have the potential to erode public trust in the rule of law. With stakes so high, it is important to understand why some states have adopted criminal justice policies that protect against wrongful convictions and why others appear reluctant to follow suit. To develop our understanding in this area, we will assess macro-level shifts in the political climate and the strength of 'innocence' advocacy organizations in each state to see if these factors influence state adoption of wrongful conviction legislation.

In particular, we will focus our attention on whether or not states that are politically conservative are less inclined to pass laws that favor criminal defendants so as to protect against wrongful conviction. Additionally, organizations that make-up the growing "Innocence Network" have emerged across the country in order to provide relief for inmates fighting their conviction, to advocate for legislative change to help the wrongfully convicted, and to prevent future miscarriages of justice. We will explore the potential influence these advocacy groups have had on legislative change. In this paper we assess the explanatory power of both accounts as well as other factors that should explain variation in the adoption of wrongful conviction legislation. The next section examines these factors and related empirical studies in more detail.

\section{Explaining the adoption of wrongful conviction legislation}

\subsection{Political climate}

Prior scholarship suggests that those interested in understanding change in criminal justice policy or practice should consider the broader political climate. These studies often base their arguments on partisan preferences for more punitive criminal justice policies (e.g. Jacobs and Helms, 2001; Jacobs and Carmichael, 2001). Specifically, many scholars have noted the link between political conservatism and punitiveness (e.g. Unnever and Cullen, 2010; Bobo and Johnson, 2004). Empirical research has linked political conservatism to higher incarceration rates (Jacobs and Carmichael, 2001) and a greater use of capital punishment (Jacobs and Carmichael, 2004). This relationship is thought to exist because of conservative political ideologies that stress free will and individual responsibility for both one's successes and, more importantly for our purposes here, one's misdeeds. Following these basic assumptions about criminal behavior, conservative ideology tends to favor punitive criminal justice policies that stress individual responsibility and harsh sanctions for miscreants so as to deter others who are also inclined to violate societal norms. More broadly, conservatives tend to believe that one of the leading causes of the 'crime problem' is criminal courts that are too lenient and the possibility that too many of the guilty are getting away with their crimes because of 'technicalities' (Beckett, 1997). Following this logic, conservatives may be less inclined to support the strengthening due process rights such as protections against wrongful convictions because adding such safeguards could (in their view) increase the chance that individuals are not held responsible for their criminal actions. But how would these ideological positions translate into legislative change related to criminal justice policy?

Two mechanisms have been identified which help us better understand how political ideology may influence policy outcomes. The first relates to citizen preferences. It stands to reason that the public could and should (through the democratic process) weigh-in on criminal justice policy preferences. Ideally, we would assess the explanatory power of some public opinion measure about possible statutory changes related to wrongful convictions within each state. Unfortunately, such measures do not exist. In their absence, we follow other scholars who use voting behavior as a gauge of public opinion combined with our understanding of conservative ideological preferences for certain criminal justice policies that may be less favorable toward changes to wrongful conviction statutes. A rather sizable body of literature supports such an approach. Weidner and Frase (2003), for instance, show that states where more voters supported a Republican presidential candidate had higher rates of incarceration. Caldeira and Cowart (1980) report that national Republican leaders spend more on criminal justice expenses such as law enforcement and imprisonments than Democrats. States with high percentages of Republican voters are more likely to retain the death penalty (Jacobs and Carmichael, 2002) and Jacobs et al. (2007) found that death row inmates are executed more quickly in states in which more voters support Republican presidential candidates because, presumably, prosecutors, appellate justices, and governors will face stronger pressures to allow executions to proceed quickly.

A similar mechanism could be operating when legislators consider adopting wrongful conviction statutes. If this is the case, those states where the public is more likely to support Republican candidates should be less likely to support legislative adaptations that would strengthen due process rights. In their analysis of public opinion data, Zalman et al. (2012) write that the issue of innocence is more likely to be supported by liberals. In many states, even after proving their innocence, the 
wrongly convicted find it difficult to distinguish themselves from the justly convicted and continue to face the stigma of felony conviction and imprisonment in a society that largely reports high levels of confidence in the criminal justice system as a whole (Whitman, 2003). Some legal scholars have disputed this point, arguing that the issue of wrongful convictions should cross ideological lines because identifying and convicting the correct offender is in the interest of liberals and conservatives alike (Findley, 2008; Mumma, 2004). While insightful, these commentaries have not been corroborated with research-based findings. This study is the first to empirically test whether political ideology explains the presence of a variety of wrongful conviction statutes.

Beyond ideological preferences of individual citizens, though, some have argued that politicians have used criminal justice policies as a partisan tactic to gain votes. A number of scholars have documented how Republican politicians have used law-and-order issues in their campaigns to gain electoral support from citizens, particularly working class whites who resent the underclass and who are more likely to live where violent crime risks are greater (Edsall and Edsall, 1991; Garland, 2001; Oliver, 2003:126). Republican campaigns have used this crime issue to capture anti-minority voters (e.g. Beckett, 1997) and once elected, Republicans appear to adhere to their tough-on-crime promises (Stucky et al., 2005; Western, 2006). For example, greater Republican political strength has been associated with increased imprisonments (Jacobs and Helms, 1996; Jacobs and Carmichael, 2001). Beyond the use of incarceration, prior research has also shown that partisanship is particularly important when predicting crime-control outcomes that are ideologically-charged such as the death penalty. Capital punishment has been an important issue in many state political campaigns (Costanzo, 1997) and research shows that the party in power determines how (and whether) the death penalty operates. States with strong Republican parties are more likely to retain the death penalty as a possible sanction (Jacobs and Carmichael, 2002; Author cite). Furthermore, Jacobs and Kent (2007) found that the number of executions in the U.S. increased after elections of Republican candidates.

In the only study to empirically examine the presence or absence of statutes regarding wrongful convictions, Owens and Griffiths (2012) propose that the ideological composition of governmental elites should influence whether states have wrongful compensation statutes. They analyze the existence of state statutes that provide compensation for the wrongly convicted, but do not find that government ideology affects the presence or absence of these laws.

To explain this null finding they suggest that perhaps states enact compensation statutes not as a means of social justice but instead in order to limit the reparations the wrongfully convicted receive so that they do not create additional civil litigation costs to the state. This aligns with findings that the wrongfully convicted are often unable to collect compensation for various reasons (Norris, 2012). Regardless of the interpretation, this study only analyzed one type of law related to wrongful convictions, and one that intends to ameliorate rather than prevent them. We believe that, in line with the research on other criminal justice system practices, government ideology should affect a wide range of wrongful conviction statutes, so states with Republican politicians should be less likely to adopt this legislation.

\subsection{Advocacy organization activity}

Political sociologists and conventional wisdom have long held that policy outcomes are influenced by interest group activities aimed at producing a particular outcome (Thomas and Hrebenar, 2004; Walker, 1991). Two potential mechanisms are relevant here. First, advocacy groups can increase public awareness and opinions about a particular issue through public education campaigns. Second, interest groups can directly lobby state officials to champion legislative change. While much scholarly debate still exists in this area and the empirical evidence continues to be inconclusive (See Baumgartner and Leech, 1998 for elaboration), interest group action has been associated with legislative change in areas as diverse as civil rights (e.g. McAdam, 1999), equal employment rights (e.g. Santoro, 2002), women's rights (e.g. Soule et al., 1999), women's right to serve as jurors in criminal trials (McCammon, 2012), the environment (Agnone, 2007), taxation (Jacobs and Helms, 2001), hate crimes (Jenness, 1999), and gay rights (Kane, 2003) among other issues. Although no prior research has examined the role that interest groups may have on the passage of wrongful conviction legislation, the studies above suggest that this factor could be relevant here.

\subsubsection{A brief look at wrongful conviction advocacy}

Both the death penalty abolitionist movement and the innocence movement have used cases of factually innocent inmates who were exonerated, often due to the retesting of DNA evidence, to frame their causes. Such efforts appear to have had some influence on public sentiments. Recent public opinion studies have shown, for instance, that the innocence frame has been successful in reducing support for capital punishment (Baumgartner et al., 2008) with a 14 percent drop in support during the late 1990s (Zalman et al., 2012), a time period characterized by a substantial rise in DNA exonerations. Stories of innocent people convicted using faulty eyewitness accounts or junk science are striking reminders of the fallibility of the criminal justice system. Siegel (2005) writes, "While these kinds of extraordinary events will no doubt remain the calling card of the innocence movement, they ought not to obscure the simple fact that most of the erroneous or unjust results that emerge from our criminal justice system are the consequence not of extraordinary events, but of the ordinary operation of a flawed system." (p. 1223). These spectacular stories are most useful to the movement because they resonate with the public, compared to less eye-catching (though perhaps more common) problems related to inadequate funding for indigent defense systems, overzealous prosecutors, or technical issues such as flawed discovery rules (Siegel, 2005).

This movement has relied on legal aide organizations, many of which are part of the Innocence Network, to expose the problem of wrongful convictions. As of 2013, 50 Innocence Network organizations operate across the United States, each 
employing law students to examine cases of suspected wrongful convictions in the state. The legal activists that comprise these organizations provide the evidence and the legal expertise integral to the success of the movement. Beyond identifying and working to rectify specific cases of wrongful conviction, these organizations have made policy change a central component of their mission. In fact, many state chapters of the Innocence Project have a staff position dedicated to pursuing state legal reform. Evidence of this advocacy groups successful lobbying efforts abound. For example, members of the Innocence Project in Texas worked alongside lawyers, exonerees, legislators and the family of Tim Cole, who was wrongfully convicted of rape, to successfully lobby for legislative change that later became known as the Tim Cole Act. This 2009 act allowed for Texas inmates who are wrongfully convicted to receive between $\$ 50,000$ and $\$ 80,000$ per year of incarceration as compensation. Similarly, the Illinois Innocence Project successfully advocated for legislation that requires videotaping of interrogations and currently supports a bill that would allow inmates who have plead guilty to use DNA technology to fight their conviction (many states restrict this right to those who did not accept plea bargains). While these are only a few examples of legislative involvement of these organizations, it seems plausible that states where Innocence Network members have dedicated the most resources will be more likely to adopt wrongful conviction legislation.

But Innocence Organization success likely depends on a state's political climate. The ideological polarization regarding criminal justice policies lies largely along party lines in the United States so the ability of groups like the Innocence Network in any state to effect legislative change may be contingent on the public's political preferences. That is, organizational success should depend partly on whether the public is likely to support their cause. Our discussion of partisanship above assumes that Republican voters are less likely to support pro-defendant legislation so it follows that any positive effect of Innocence Organizations on wrongful conviction laws should be reduced in states with a Republican voting public. Organizational success may also depend on the support of the lawmakers and state executives that sign bills into laws. Because Republican politicians have historically been "tough on crime" they should be reluctant to pass laws that seem to support criminal defendants so it stands that Innocence Organization efforts should be stymied in states with both executive and legislative branches controlled by Republicans. We investigate both of these interactive possibilities.

\subsection{Additional factors}

\subsubsection{Crime}

Differences across states in the prevalence of crime should also influence criminal justice policy. Through the media, the public is regularly informed about the extent of crime (especially violent crime) in their communities. This heightened awareness should create fear of victimization among the public that, in turn, may spark demands for harsher punishment and possibly less concern for due process rights afforded to criminal suspects. Some empirical evidence supports such a claim. For instance, Jacobs et al. (2007) reported that execution probabilities are greater in states that have the highest murder rates. If similar mechanisms operate when states consider wrongful conviction legislation, we should expect to see states with high violent crime rates adopting fewer protections against system errors such as wrongful convictions.

\subsubsection{African American presence and unemployment}

Other factors may influence public perceptions about the threat of crime and, by extension, criminal justice policy preferences. Seminal work by Quillian and Pager (2001) offered compelling evidence that perceptions of the incidence of crime have less to do with actual rates of crime and more to do with stereotypes about the kinds of people who commit crime. They find that after controlling for crime rates, the strongest predictor of the public's perception of the crime problem is the size of the African American population and the proportion of low-income individuals. Some empirical evidence supports this idea. Larger percentages of African American residents have been associated with higher execution probabilities (Jacobs et al., 2007), more individuals in jails (Carmichael, 2005), in prisons (Jacobs and Carmichael, 2001), more severe sanctioning of juvenile offenders (Carmichael and Burgos, 2012) and legislation allowing the use of the death penalty in U.S. states (Jacobs and Carmichael, 2002). Following a similar logic, we should expect that states with larger African American populations and those with a larger economic underclass will be less inclined to adopt criminal justice policies that protect due process rights.

\section{Data, measures and estimation}

We test the hypotheses outlined above using a dataset containing social and political variables for all 50 states. We gathered annual data for each of our independent variables between 2000 and 2010 providing 11 years of data for each state. We obtain annual data for the percentage African American in each state using interpolation between 2000 and 2010 as the most accurate accurate figures are derived from the decennial Census. Independent variables measuring the political climate were gathered using government sources and crime data was taken from Uniform Crime Reports for each year.

\subsection{The dependent variables}

Data for the dependent variables was taken from the Innocence Project web site (http://www.innocenceproject.org). The Innocence Project is an advocacy organization founded in 1992 by prominent defense lawyers Barry Scheck and 
Peter Neufeld. Their mission is to provide the legal representation and research required to prove the innocence of prisoners, primarily through the testing of DNA evidence. Beyond working to free innocent people from prisons across the U.S., the Project aims to "bring substantive reform to the system responsible for their unjust imprisonment." As part of their efforts, the lawyers, law students, and other staff have compiled a comprehensive dataset outlining those states that have revised their statutes in ways that may reduce the likelihood of wrongful convictions. In addition to the compilation of statutory modifications, the Project has also created a detailed account of exonerations in each state.

One element of the Innocence Project's advocacy work is the development of model legislation for state legislators to consider if they wish to reduce the likelihood of wrongful convictions. Recommendations include instituting laws to allow inmates' access to post-conviction DNA testing, laws that require the preservation of DNA evidence, reform to eyewitness procedures, protections against false confessions, crime lab oversight, regulations related to the use of informants, and financial compensation for those individuals wrongfully convicted of a crime. A number of states have implemented all or some of these changes, with most changes taking place between the years 2000 and 2010 . Our goal is to develop a multivariate model containing theoretically derived variables that can help us better understand why some states have made these statutory changes and to identify any contextual factors within states that make such passage more or less likely.

To this end, our dependent variable is a cumulative index created by summing the number of pieces of legislation that each state has passed. We gave each state one point for each of the above statutory changes they made to reduce wrongful convictions. States vary substantially in the extent to which they have adopted these pieces of model legislation. We argue that this cumulative score is particularly useful as it acts as a strong gauge of each state's overall willingness to protect defendants against wrongful conviction rather than the adoption of a single piece of legislation. The first type of law requires the preservation of DNA evidence after a criminal trial. This particular piece of legislation is perhaps the most critical of all the recommendations advanced by the Innocence Project because without the preservation of DNA evidence the exoneration of the roughly 300 individuals assisted by the Project would not have been possible. Laws that require preservation of evidence are essential in the fight against wrongful convictions because DNA access laws are useless without DNA to test. Despite its importance, only about half the states have adopted statutes requiring the preservation of DNA evidence after a criminal trial. Based on data taken from the Innocence Project's web site, we construct a dummy variable coded " 1 " if the state has adopted or modified statutes requiring evidence preservation after a criminal trial. Also from this data source we construct 4 additional dummy variables indicating whether or not the state has adopted the following statutes: a requirement to allow defendants access to DNA evidence, a law that mandates recording of interrogations in order to avoid false confessions, one that requires improved eyewitness tests (to avoid biased line-up procedures such as the "show up" procedure discussed earlier) and one that guarantees some sort of monetary compensation for the exonerated. Again, these scores are then summed to create the total score for each state.

\subsection{The explanatory variables}

Data for the explanatory variables was taken from either the U.S. Census, the Innocence Project website, or Uniform Crime Reports. Measures for the explanatory variables are as follows:

\subsubsection{Political explanations}

These include measures of Republican control of state governance and a proxy measure of citizen ideological preferences. The strength of the Republican Party in each state is operationalized using two separate variables. The first is a dummy variable coded " 1 " if Republicans control the state legislature using a $55 \%$ threshold. The second factor is a dummy variable coded " 1 " if the state has a Republican governor. We also include a separate dummy variable indicating states where the Republican Party controls both the governor's office and the state legislature. In addition to these three political variables, we also include a proxy for citizen ideology based on voting in Presidential elections. As mentioned above, Republican candidates have been more closely associated with law and order appeals during campaigns, and conservative ideology more broadly tends to be strongly aligned with overarching sentiments that the justice system is too "soft" on criminals and that there are too many procedural protections for criminals such that the guilty will be protected from punishment. Without exception, the types of statutory changes recommended by advocacy groups like the Innocence Project aim to increase these procedural protections to ensure that innocent individuals are not incarcerated. As such, these policies would run counter to the Republican Party doctrine related to criminal justice. While not a perfect indicator of public resistance or support for wrongful conviction legislation, we use a dummy variable coded " 1 " if the majority (over $50 \%$ ) of the citizens in each state voted for the Republican candidate for President in presidential elections since 2000 to capture the extent to which the public is in favor of protections against wrongful convictions. Data for all the political variables was taken from the U.S. Census.

\subsubsection{Advocacy organizations and evidence of wrongful convictions}

To test the influence that advocacy organizations have on legislative change, we include a count of Innocence Network organizations in each state to see if the presence of these organizations has an influence on the passage of adoption of wrongful conviction statutes. Our assumption is that more organizations represent greater organizational capacity in a particular state, thereby, improving the movement's influence on political outcomes. Owens and Griffiths (2012) report that having more exonerations in a given state heightens public awareness of wrongful convictions and should therefore increase the likelihood of legislative change in this area. They find that the number of DNA exonerations is the strongest predictor of 
whether or not a state has laws aimed at compensating the wrongfully convicted. Our measure includes the total number of exonerations in each state per year. Data on the location of Innocence Network organizations and the number of exonerations was taken directly from the Innocence Project website. Organizations that cover multiple states were counted for each state in which they operate.

\subsubsection{Additional factors}

All of our models account for additional theoretically derived measures that may contribute to the adoption of wrongful conviction legislation in a given state. Specifically, we account for variations in crime by including the violent crime rate in each state taken from the FBI's Uniform Crime Reports. To assess the influence that high unemployment may have on wrongful conviction legislation, all our models include the unemployment rate taken from the Bureau of Labor statistics. Finally, we assess the influence of African American presence on the adoption of wrongful conviction legislation with their percentage share of the overall state population.

\subsection{Estimation}

We employ standard pooled time-series regression (Ordinary Least Squares Regression) to assess the hypotheses outlined above. We predict the number of wrongful conviction statutes advanced in the Innocence Project's model legislation that have been adopted in each of the 50 states. The outcome is normally distributed so OLS estimates should be reliable and accurate. The pooled time-series approach we use has a number of advantages but, in particular, it allows us to assess how shifts in our set of explanatory variables within each state and over time may influence the adoption of these specific pieces of legislation. It is worth noting that all of our models build in an implicit causal order by using explanatory variables lagged one year behind the outcome (e.g. values for the explanatory variables in 2000 are used to predict our outcomes in 2001). We also employ a series of corrections to ensure our results are accurate. First, we use robust standard errors to correct for potential heteroskedasticity in all of our models. Additionally, because the Wooldridge Test for autocorrelation showed that our panel data suffered from first-order autocorrelation we include an autoregressive term (AR1) in all off our models. Finally, the Variance Inflation Factor (VIF) was well below 2.5 suggesting that multicollinearity is not degrading our results.

\section{Results}

\subsection{Descriptive statistics}

Table 1 presents the means, standard deviations, and the range for each of our variables. The table illustrates how varied states are in their willingness to adopt legislation aimed at reducing or eliminating wrongful convictions. At the end of our time period analyzed (2010), nearly every state (96\%) allowed defendants access to DNA evidence but only 60 percent of states have statutes that require the preservation of DNA evidence after a criminal trial. We also see that over half of U.S. states require some type of compensation for those exonerated but only 34 percent require that police interrogations be recorded and just 16 percent of U.S. states have modified their statutes to reform eyewitness practices. We also see from Table 1 that states vary substantially in the degree to which they are willing to adopt this type of legislation; however, to the extent they have adopted other pieces of model legislation. On average, states have adopted 2.6 of the model statutes by 2010. Five states have adopted all of the model legislation outlined by the Innocence Project (Connecticut, Maryland,

Table 1

Predicted signs and descriptive statistics ( $N=550$ state years).

\begin{tabular}{|c|c|c|c|c|c|c|}
\hline Variable & Predicted sign & Mean 2001 & Mean 2010 & St. dev. overall & Min overall & Max overall \\
\hline 1 = Preserve Evidence Legislation & DV & .26 & .60 & .50 & 0 & 1 \\
\hline 1 = Eyewitness Reform & DV & .02 & .16 & .29 & 0 & 1 \\
\hline 1 = Record Police Interrogations & DV & .04 & .34 & .39 & 0 & 1 \\
\hline $1=$ State Compensation & DV & .28 & .54 & .49 & 0 & 1 \\
\hline $1=$ DNA Access & DV & .56 & .96 & .38 & 0 & 1 \\
\hline Total \# of Wrongful Conviction Statutes & DV & 1.16 & 2.6 & 1.17 & 0 & 5 \\
\hline Violent Crime Rate & - & 420.34 & 366.45 & 170.32 & 78.20 & 822.70 \\
\hline$\%$ African American & \pm & 10.25 & 11.14 & 9.61 & .34 & 37.4 \\
\hline \% Unemployed & \pm & 4.47 & 8.74 & 2.10 & 2.5 & 13.8 \\
\hline 1 = Republicans control of State Legislature & - & .36 & .32 & .49 & 0 & 1 \\
\hline $1=$ Republican Governor & - & .58 & .46 & .50 & 0 & 1 \\
\hline 1 = Majority Republican Presidential Vote & - & .54 & .40 & .50 & 0 & 1 \\
\hline $1=$ Rep. Governor and Control of Legislature & - & .24 & .22 & .44 & 0 & 1 \\
\hline \# of Exonerations in the State & + & .38 & .36 & .86 & 0 & 6 \\
\hline \# of Innocence Organizations in State & + & 1.42 & 1.42 & .96 & 0 & 5 \\
\hline
\end{tabular}

DV = Dependent Variable. 


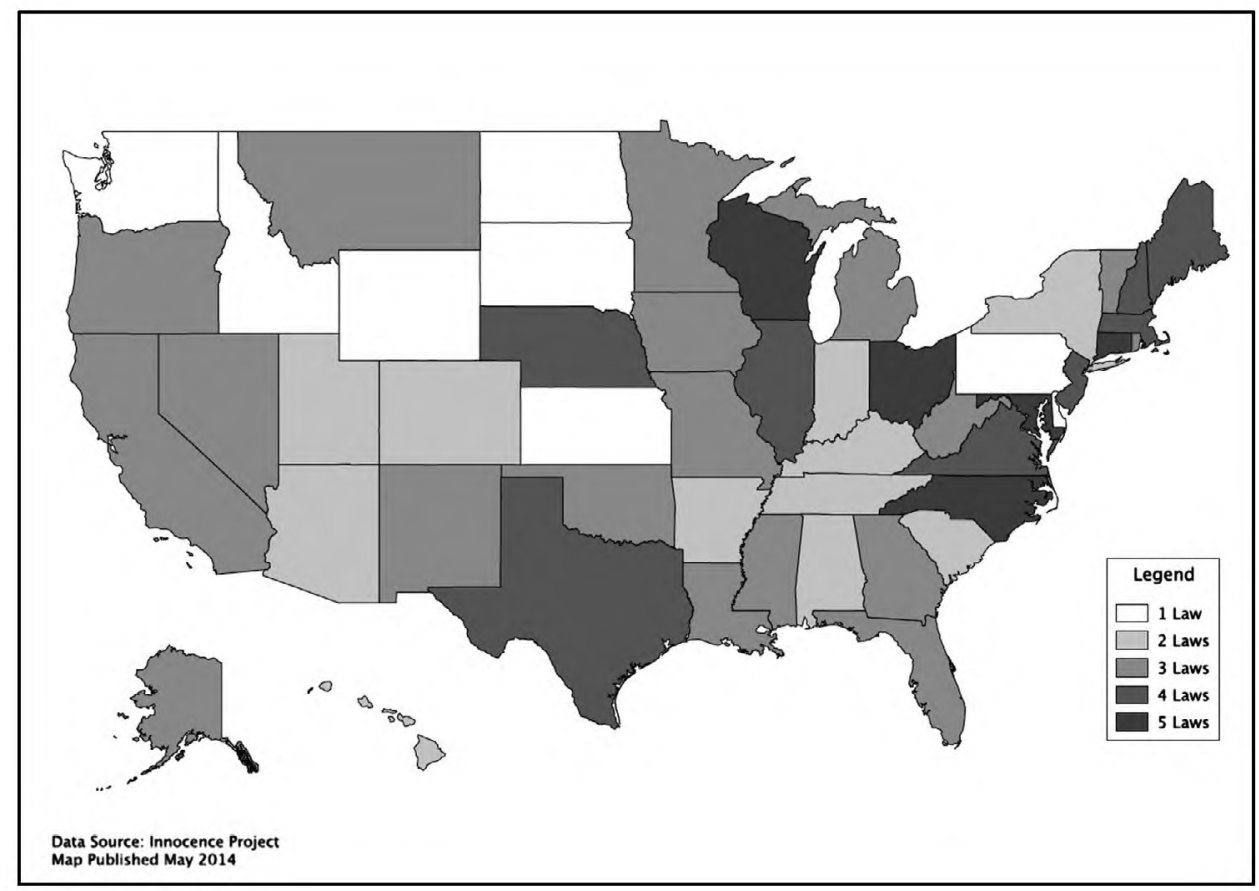

Fig. 1. Number of wrongful conviction Laww by State.

Ohio, North Carolina, Wisconsin) while eight states have adopted only one (Delaware, Idaho, Kansas, North Dakota, Pennsylvania, South Dakota, Washington, Wyoming). Fig. 1 shows the distribution of laws by state in 2010, with darker shaded states having passed more of these laws. It is also worth noting that, on average, states had roughly 1.6 exonerations and states have anywhere from zero to five Innocence Project offices. It is noteworthy that those policies that influence the way police conduct their investigations (eyewitness reform and the recording of police interrogation) are the least likely to be adopted of any type of legislation. Unfortunately, these practices tend to be the source of most wrongful convictions.

Table 2 presents the bivariate correlation matrix. It is noteworthy that for most of our dependent variables the strongest positive bivariate relationship is the number of Innocence Project offices in the state and the strongest negative relationship is the percentage Republican in the state legislature. Also, a positive bivariate relationship exists between African American presence and most of our outcome variables and exonerations appear to have a stronger positive association with the overall count of wrongful conviction statutes and state compensation legislation. The multivariate analyses that follow will allow us to determine if these factors are statistically significant when considered together.

\subsection{Multivariate analyses}

Table 3 presents the results from our multivariate analyses. Table 3 presents OLS regression coefficients predicting the total number of wrongful conviction statutes in the state. ${ }^{3}$

In Table 3 we predict the total number of statutes related to wrongful convictions/exonerations adopted by each state. Model 1 is a limited specification that includes considers the control variables and the political climate. This early model shows that African American presence significantly increases the number wrongful conviction statutes in a state. Additionally, the regression estimates show that a significant and positive relationship exists between the unemployment rate and the number of wrongful conviction statutes adopted in the state. The positive effects of these variables are unexpected though we offer some interpretations for these findings in the conclusions. Turning to the theoretically important variables, this model shows that only one of the three measures of political climate is significant. States with a Republican-controlled legislature have more laws that prevent or ameliorate wrongful convictions, but the party of the Governor does not matter, and having both a Republican controlled legislature and Governor does not predict the frequency of these laws.

Model 2 introduces our measure of public opinion to the variables in our first model and this variable is significant in the expected direction. States that "went red" in Presidential elections have more laws that prevent or ameliorate wrongful convictions. States with Republican legislatures continue to be significantly less likely to adopt such legislation and the effects of the controls for unemployment and African-American presence remain the same.

\footnotetext{
${ }^{3}$ We ran a Ramsey-reset test for omitted variable bias and the results suggested that significant misspecification error does not bias our results.
} 
Table 2

Correlation matrix ( $N=550$ state years).

\begin{tabular}{|c|c|c|c|c|c|c|c|c|c|c|c|c|c|c|c|}
\hline Variable & 1 & 2 & 3 & 4 & 5 & 6 & 7 & 8 & 9 & 10 & 11 & 12 & 13 & 14 & 15 \\
\hline 1. \# of Wrongful Conviction Statutes & 1.00 & & & & & & & & & & & & & & \\
\hline 2. 1 = Preserve Evidence Legislation & .67 & 1.00 & & & & & & & & & & & & & \\
\hline 3. 1 = Eyewitness Reform & .51 & .14 & 1.00 & & & & & & & & & & & & \\
\hline 4. 1 = Record Police Interrogations & .51 & .14 & .23 & 1.00 & & & & & & & & & & & \\
\hline 5. 1 = State Compensation & .61 & .15 & .28 & .20 & 1.00 & & & & & & & & & & \\
\hline 6. DNA Access & .57 & .35 & .14 & .03 & .06 & 1.00 & & & & & & & & & \\
\hline 7. Violent Crime Rate & .02 & .12 & -.08 & -.07 & -.00 & .05 & 1.00 & & & & & & & & \\
\hline 8. \% African American & .20 & .20 & .19 & -.17 & .15 & .17 & .53 & 1.00 & & & & & & & \\
\hline 9. \% Unemployed & .31 & .23 & .10 & .12 & .10 & .30 & .15 & .19 & 1.00 & & & & & & \\
\hline $\begin{array}{l}\text { 10. } 1 \text { = Republicans control of State } \\
\text { Legislature }\end{array}$ & -.20 & -.18 & -.05 & -.11 & -.18 & -.02 & -.10 & -.17 & -.13 & 1.00 & & & & & \\
\hline 11. 1 = Republican Governor & -.21 & -.01 & -.18 & -.20 & -.16 & -.12 & .01 & .01 & -.07 & .22 & 1.00 & & & & \\
\hline $\begin{array}{l}\text { 12. } 1 \text { = Majority Rep. Presidential } \\
\text { Vote }\end{array}$ & -.25 & -.15 & -.10 & -.31 & -.11 & -.07 & .07 & .16 & -.15 & .43 & .20 & 1.00 & & & \\
\hline $\begin{array}{l}\text { 13. } 1 \text { = Rep. Governor and Control of } \\
\text { Legislature }\end{array}$ & -.15 & -.09 & -.09 & -.11 & -.15 & -.01 & -.06 & -.12 & -.08 & .74 & .54 & .41 & 1.00 & & \\
\hline 14. \# of Exonerations in the State & .17 & .19 & .02 & -.05 & .20 & .06 & .17 & .19 & .05 & .06 & .09 & .04 & -.04 & 1.00 & \\
\hline $\begin{array}{l}\text { 15. \# of Innocence Organizations in } \\
\text { State }\end{array}$ & .22 & .28 & -.05 & -.03 & .19 & .13 & .12 & .24 & .07 & .01 & .05 & -.09 & -.14 & .02 & 1.00 \\
\hline
\end{tabular}

Table 3

Pooled time-series regression estimates for the sum of wrongful conviction statutes in the state.

\begin{tabular}{|c|c|c|c|c|c|}
\hline & Model 1 & Model 2 & Model 3 & Model 4 & Model 5 \\
\hline $\begin{array}{l}\text { Control variables } \\
\text { Violent crime rate } \\
\% \text { African American } \\
\% \text { Unemployed }\end{array}$ & $\begin{array}{l}-.07(.06) \\
.03^{*}(.01) \\
.07^{* *}(.02)\end{array}$ & $\begin{array}{l}-.07(.06) \\
.04^{*}(.01) \\
.06^{* 4 *}(.02)\end{array}$ & $\begin{array}{l}-.07(.06) \\
.03^{*}(.01) \\
.06^{*}(.02)\end{array}$ & $\begin{array}{l}-.09(.06) \\
.03^{*}(.01) \\
.06^{* *}(.02)\end{array}$ & $\begin{array}{l}-.08(.06) \\
.03^{*}(.01) \\
.06^{*}(.02)\end{array}$ \\
\hline $\begin{array}{l}\text { Political variables } \\
1=\text { Republicans Control of State Legislature } \\
1=\text { Republican Governor } \\
1=\text { Rep. Governor and Control of Legislature } \\
1=\text { Majority Republican Presidential Vote }\end{array}$ & $\begin{array}{l}-.27^{*}(.12) \\
-.04(.09) \\
.06(.13) \\
-\end{array}$ & $\begin{array}{l}-.23^{*}(.12) \\
-.04(.09) \\
-.06(.13) \\
-.35^{* *}(.13)\end{array}$ & $\begin{array}{l}-.23^{*}(.12) \\
-.04(.09) \\
.06(.13) \\
-.33^{*}(.13)\end{array}$ & $\begin{array}{l}-.23^{*}(.12) \\
-.04(.09) \\
.08(.13) \\
-.25^{*}(.14)\end{array}$ & $\begin{array}{l}-.23^{*}(.12) \\
-.04(.09) \\
.06(.13) \\
.33^{*}(.13)\end{array}$ \\
\hline $\begin{array}{l}\text { Exonerations and advocacy groups } \\
\text { \# of Exonerations in the State } \\
\text { \# of Innocence Organizations in State } \\
\text { Innocence Organizations X Majority Republican Presidential Vote } \\
\text { Innocence Organizations X Rep. Governor and Control of Legislature } \\
\text { Constant }\end{array}$ & $\begin{array}{l}- \\
- \\
- \\
- \\
1.61\end{array}$ & $\begin{array}{l}- \\
- \\
- \\
- \\
1.77\end{array}$ & $\begin{array}{l}-.00(.03) \\
.25(.12) \\
- \\
- \\
1.46\end{array}$ & $\begin{array}{l}-.00(.03) \\
.36(.14) \\
-.20^{+}(.08) \\
- \\
1.43\end{array}$ & $\begin{array}{l}.00(.03) \\
.25^{*}(.12) \\
- \\
.02(.05) \\
1.46\end{array}$ \\
\hline $\begin{array}{l}N \\
\text { Wald } \mathrm{Chi}^{2}\end{array}$ & $\begin{array}{l}550 \\
31.66\end{array}$ & $\begin{array}{l}550 \\
39.53\end{array}$ & $\begin{array}{l}550 \\
44.84\end{array}$ & $\begin{array}{l}550 \\
50.36\end{array}$ & $\begin{array}{l}550 \\
45.09\end{array}$ \\
\hline
\end{tabular}

$* P \leqslant .05$.

** $P \leqslant .01$.

*. $P<.001$. All independent variables are lagged by one year $(t-1)$. All models correct for autocorrelation using an AR 1 term

a Coefficients and standard errors divided by 100 to improve interpretation. Standard Errors in parentheses.

Model 3 introduces our two variables measuring the number of exonerations and the number of Innocence Network organizations in each state. Unlike the results from Table 3 in which we examined just the presence of single (yet important) pieces of legislation that aim to protect against wrongful conviction, we see that as the number of Innocence Network organizations increases there is a significantly higher number of statutes designed to achieve these protections for defendants. This provides strong support for claims that advocacy groups can be effective at producing legislative change.

We have yet to determine, however, whether Innocence Network success depends on the political climate. In Model 4 we investigate this possibility by adding a term that interacts the number of innocence organizations by the dummy variable that indicates whether the majority of the voters supported the Republican presidential candidate. Results persist from Model 3, and this new specification is significant and negative, so that the positive effect of Innocence organizations is reduced in states that vote Republican.

Finally, in Model 5 we investigate whether organizational success is also tempered by Republican politicians by replacing the prior interaction term with one that interacts the number of innocence organizations with a dummy that indicates whether the state has both a Republican Governor and Republican-controlled legislature. This new term is not significant but all other results persist. Overall, we see from our results in Table 3 that the presence of Innocence organizations, a Repub- 
lican controlled legislature, and a public that votes Republican are the only theoretical factors in our Models that consistently influence the number of statutory changes. It appears that Republican policymakers are less inclined to make and pass laws that strengthen due process, and a Republican public is less likely to demand these laws, but the presence of advocacy organizations can produce legislative change in this area, though their efforts are reduced in states with many Republican voters.

\subsubsection{Additional considerations}

We tested a variety of additional indicators and interactions (not shown, but available from the authors) to see if/how they may influence our outcomes. Our tests showed that the inclusion of alternative crime measures such as the murder rate or the overall crime rates (which includes both the violent and property crime rates) did not significantly influence either of our outcomes. Similarly, controls for the region of the United States, population, the economic affluence of each state (median household income), income inequality (GINI index), or the presence of religious fundamentalists, and whether or not the state allows citizens to initiate legislation through ballot initiatives did not reach the level of statistical significance in our models. In addition to tests of other potentially theoretically relevant factors, we also tried alternative specifications of some of the variables in our analyses. First, we tested additional interactions between the presence of advocacy organizations (Innocence Network organizations) with other factors including whether the state had a Republican governor, and the presence of African-Americans to see if these factors worked jointly rather than independently. Results from these interactions showed that other than the interactions reported in the models, all of our explanatory variables work independently to influence each outcome as none of the interactions reached statistical significance. Second, we included alternative combinations of the political variables in our model including states with majority republican legislatures and a democratic governor, states with democratic legislatures and a Republican governor, and so on. We report the only dyad that reached statistical significance in our final models.

Finally, to see whether these results are driven by any particular type of law included in our index, we analyzed each type of law in our index separately. We ran logistic analyses of the factors that predict each of the 5 laws (results available from authors upon request). Using the most inclusive set of covariates from our multivariate analyses to predict each type of law we found that very few covariates predicted all of these laws but the most important political factor seems to be having a largely Republican voting public. States with Republican leaning publics are less likely to have laws that require the preservation of evidence and recording of interrogations. While having either a Republican Governor or a Republican controlled legislature does not predict these laws, having both a Republican Governor and a Republican-controlled legislature impedes the passage of two out of the 5 statutes (eyewitness reform and compensation) but only at the .1 significance level. These results suggest that the analyses predicting the total number of statutes are not driven by any one particular type of law, rather, our covariates best predict variation in the overall success of legislative changes that aim to prevent or ameliorate wrongful convictions. These additional tests and specifications bolster confidence in the robustness of our findings.

\section{Conclusions}

Over the last few decades there has been a growing interest in the documented cases of wrongful convictions in the United States, particularly those identified through examination of DNA evidence. During this period, advocacy groups within what is known as the Innocence Movement have advocated for a number of legislative changes at the state level to reduce or eliminate the risks of wrongful convictions by strengthening certain due process rights. Despite calls for these protections, many states have been reluctant to adopt these statutory changes. Our goal here has been to develop a better understanding about why some states have adopted important measures to reduce the risk of wrongful convictions while others have been more reluctant. The analysis presented above explored socio-political factors as well as advocacy group presence across all 50 states over a ten year period to assess their potential influence on state adoption of specific protections against wrongful conviction. The results provide evidence that, even with the inclusion of a set of controls, the presence of advocacy groups in the state have a significant influence on state-level adoption of these statutes but their successes are tempered in states with many Republican voters. Furthermore, some aspects of the political context make statutory changes in this area of the law less likely.

We acknowledge several limitations. First, it is likely that some jurisdictions have made strides toward reducing wrongful convictions or offering compensation through ways other than legislation, though we have no way to reliably measure these local efforts. Policies have been advanced by agencies such as Prosecutors' Conviction Integrity Units (Center on the Administration of Criminal Law 2012; Ware, 2012; Vance, 2010) or police departments (Police Executive Research Forum 2013). Second, and more importantly, we acknowledge that the content of the statutes we study here vary substantially from state to state. For example, Norris (2012) analyzes the differences in state compensation laws and finds many similar themes but also important variation while Norris et al.'s (2011) content analysis of other relevant statues including eyewitness reforms shows similar discrepancies across states. While it is clear that some types of legislation may be more or less effective at reducing errors in the criminal justice system, all will likely make some improvements and all represent attempts by particular states to address the issue. For this reason, we believe our study offers important insights into the contextual factors that lead some states more likely to make meaningful changes to their wrongful conviction statutes. Yet, given 
the complexities of each of the statutes, future research might consider creating an index to rank states on the inclusiveness of their laws and might consider the changes in these laws over time.

Despite some limitations, a number of our findings provide important insights into state adoption of wrongful conviction legislations. We included controls for differences in crime, unemployment and minority presence in all of our models. Of these three controls, in the models predicting the total number of laws, only minority presence and unemployment significantly affected our outcomes. Contrary to expectations, states with high unemployment had more of these laws, however, this finding is not particularly surprising since Chiricos and Delone's (1992) meta-analysis of research that investigated the role of unemployment on criminal justice outcomes finds support for an economic threat explanation most, but not all of the time, and they report that the direction of the results varied depending on the particular outcome and level of aggregation. Also contrary to our predicted negative effect, we found that states with more African-Americans had more of these laws suggesting that unlike some other criminal justice outcomes, wrongful conviction laws are not responses to racial threat. Instead, perhaps because African Americans are overrepresented among the exonerated, politicians and the public in states who adopt these laws are more likely to be worried about miscarriages of justice. That is, concern about punishing and convicting the innocent may be an issue that is more salient in states with many African-Americans. Finally, we did not find that that punitiveness is a response to overall crime since the violent crime rate did not have a significant influence on passage of wrongful conviction legislation in any of our models. This is not surprising considering that others (e.g. Kent and Carmichael, 2014) report that crime control responses are more sensitive to high economic inequality than they are to an area's racial composition or crime rate. Others similarly find that decisions about criminal law and policy such as the hiring of municipal police are not related to shifts in the crime rate (Kent and Jacobs, 2005). Our findings here thus support the idea that changes to social control apparatuses in the U.S., including legal change, are more responsive to the social and political climate than actual levels of crime.

While these controls offered some interesting insights into the types of contextual factors associated with adoption of wrongful conviction protections, the primary interest centered on the role that the political context can play in this process. We find that the sensitizing effects of law-and-order rhetoric (Beckett, 1997) and the relative success of Republican law and order legislative candidates in some states-which may indicate a lack of concern for the wrongfully convicted-help explain why states with a majority Republican legislature are less likely to have laws that aim to prevent or ameliorate wrongful convictions. We also find that states in which more people vote for the Republican presidential candidate have fewer of these laws. These findings counter claims among innocence movement leaders and others that wrongful conviction is a valence issue that is supported by both liberals and conservatives (Findley, 2008; Mumma, 2004; Gould, 2008). Our empirical analysis instead suggests that the presence of these laws is partly explained by political affiliation of those who make these laws and the political mood of the public.

Interestingly, though, the presence of a Republican governor does not decrease a state's likelihood to institute these laws, but this finding should not be surprising as this factor does not explain the legalization of capital punishment (Jacobs and Carmichael, 2002) nor does it increase executions probabilities for those on death row (Jacobs et al., 2007) or black-white discrepancies in prison admissions (Keen and Jacobs, 2009). Furthermore, states with both a Republican Governor and Republican controlled Legislature are not any more likely to have more of these laws, suggesting that it is indeed the legislature that has the greatest influence on the passage (that is, lack of passage) of these pro-defendant laws. Voting trends and legislative activity may be better gauges of political climate than the party of the Governor for two reasons. First, given the low voter turnout in most U.S. elections, presidential election data provides us with a good measure of the public's political preferences because turnout is generally higher. And second, legislators should have a more direct effect on changes in the law than state executives, so it makes sense that the political affiliations of the legislature predict legal change while the party of the Governor does not.

What does increase the likelihood of states passing multiple wrongful conviction laws is the presence of Innocence Network organizations. The prior studies that investigated state differences in this legislation (Norris et al., 2011; Norris, 2012) did not test whether Innocence organizations affect variation across place, but political science logic and theory suggest that interest groups should matter. Though we recognize that other relevant interest groups exist, we focused on the Innocence Network, which is the most organized source of legal protections for the wrongfully convicted in the United States. We found that states with more Innocence Network organizations are nearly two-and-a-half times more likely to have laws requiring the preservation of DNA evidence after a criminal trial than those without an office in the state. ${ }^{4}$ We find that states with more innocence network organizations have more laws aimed at preventing wrongful convictions and aiding those who are victims of miscarriages of justice. Yet we offer an important caveat that shows that the relationship between organizational mobilization and legislative outcomes is more complex. We find that their success depends on partisanship because the effect of these organizations is reduced in states that vote Republican suggesting that these organizations' efforts appear to be stymied by conservative publics who may be reluctant to support pro-defendant legislation. Overall, these findings support the idea that

\footnotetext{
${ }^{4}$ We acknowledge that a strong Innocence Movement may create or mobilize a countermovement. Given that the laws we study here are most relevant to procedures used by law enforcement agencies and prosecutor's offices (i.e. laws that require certain eyewitness procedures or recorded interrogations) it is likely that these agencies will not support pro-defendant legislation. One reviewer suggested that the corrections officer lobby in California, for example, is quite strong and might be capable of mobilizing against the types of laws we study here. While we are unable to locate a comprehensive course of "countermovements", resistance to the laws we study should be expected (and therefore constant) across states so we do not believe that our inability to control for this factor compromises the overall integrity of our analyses.
} 
interest group action such as lobbying and public education are paying off at least when it comes to their ability to influence criminal justice policies, but these groups become less effective in the context of a Republican-leaning public.

Finally, perhaps our most important and unexpected finding is that the frequency of discovered wrongful convictions in a state does not affect its likelihood of implementing legislative changes aimed at preventing wrongful convictions. Certainly, we would expect that states with many discovered cases of wrongful convictions would be the first to pass laws aimed at reducing system errors. ${ }^{5}$ Instead, we find evidence that advocacy groups have the power to affect legal change, and their efforts are more successful when they are not countered by a majority Republican voting public.

While these are important findings in themselves, the results have larger implications for pro-defendant causes. Given the important impact the innocence movement has had on the anti-death penalty movement in the U.S. (Baumgartner et al., 2008), our findings suggest that organizational activity by the Innocence Movement has the ability to effect important legal changes extending beyond locating and exonerating the wrongfully convicted among those currently incarcerated. ${ }^{6}$ National level surveys suggest that since the innocence movement began, more Americans oppose the death penalty because of the fear of wrongful conviction. In 1991, only $11 \%$ of Americans listed wrongful convictions as a reason for opposing capital punishment, but this percentage increased to $25 \%$ in 2003 (Jones, 2005), after the Innocence movement made great progress in exonerating innocent people in prison. In 2000, Gallup reported that $92 \%$ of Americans believed that prisoners should have the right to DNA evidence to fight their conviction. These figures and our findings suggest that the legislative impact of the innocence movement has the potential to extend to other important movements in the criminal justice system.

\section{References}

Agnone, Jon, 2007. Amplifying public opinion. Soc. Forces 85, 1593-1620.

Baumgartner, Frank R., Leech, Beth L., 1998. Basic Interests: The Importance of Groups in Politics and in Political Science. Princeton University Press, Princeton, NJ.

Baumgartner, Frank R., DeBoef, Suzanna L., Boydstun, Amber E., 2008. The Decline of the Death Penalty and the Discovery of Innocence. Cambridge University Press, New York.

Beckett, Katherine, 1997. Making Crime Pay. Oxford Press, New York.

Bobo, Lawrence D., Johnson, Devon, 2004. A taste for punishment: black and white Americans' views on the death penalty and the war on drugs. Du Bois Rev. 1, 151-180.

Borchard, E.M., 1932. Convicting the Innocent: Sixty-five Actual Errors of Criminal Justice. Doubleday, Garden City, NY.

Caldeira, Greg A., Cowart, Andrew T., 1980. Budgets, institutions, and change: criminal justice policy in America. Am. J. Polit. Sci. 25, 413-438.

Carmichael, Jason T., 2005. The determinants of jail admission rates across large U.S. cities: an analysis of racial and ethnic threat theory. Soc. Sci. Res. 34 , 538-569.

Carmichael, Jason T., Burgos, Giovani, 2012. Sentencing juvenile offenders to life in prison: the political sociology of juvenile punishment. Am. J. Crim. Just. $37,602-629$

Chiricos, Theodore G., Delone, Miriam, 1992. Labor surplus and punishment: a review and assessment of theory and evidence. Soc. Probl. 39, 421-446.

Cicchini, Michael D., Easton, Joseph G., 2010. Criminal law: reforming the law on show-up identifications. J. Crim. Law Criminol. 100, $381-413$.

Collins, John M., Jarvis, Jay, 2009. The wrongful conviction of forensic science. Forensic Sci. Policy Manage. 1, 17-31.

Costanzo, Mark, 1997. Just Revenge: Costs and Consequences of the Death Penalty. St. Martin's, New York.

Edsall, Thomas B., Edsall, Mary D., 1991. Chain Reaction. W.W. Norton, New York.

Findley, Keith A., 2008. Toward a new paradigm of criminal justice. How the innocence movement merges crime control and due process. Texas Tech Law Rev. 41, 647-656.

Forst, B., 2004. Errors of Justice: Nature, Sources, and Remedies. Cambridge University Press, Cambridge, UK.

Free Jr., Marvin D., Ruesink, Mitch, 2012. Race and Justice: Wrongful Convictions of African American Men. Reiner Publishers, Boulder, Co.

Garland, 2001. The Culture of Control: Crime and Social Order in Contemporary Society. University of Chicago Press, Chicago.

Garrett, Brandon L., 2011. Convicting the Innocent: Where Criminal Prosecutions Go Wrong. U.S. President and Fellows of Harvard College

Gould, Jon B., 2008. The Innocence Commission: Preventing Wrongful Convictions and Restoring the Criminal Justice System. New York University Press, New York.

Gottschalk, Marie, 2006. The Prison and the Gallows: The Politics of Mass Incarceration in America. Cambridge University Press, New York.

Huff, C.Ronald, Rattner, Arye, Sagarin, Edward, 1996. Convicted but Innocent: Wrongful Conviction and Public Policy. Sage, Thousand Oaks, California.

Jacobs, Carmichael, 2002. The political sociology of the death penalty: a pooled time-series analysis. Am. Sociol. Rev. $67,109-131$.

Jacobs, David, Carmichael, Jason T., 2001. The politics of punishment across time and space: a pooled time- series analysis of imprisonment rates. Soc. Forces $80,61-89$.

Jacobs, David, Carmichael, Jason T., 2004. Ideology, social threat, and death sentences: capital sentencing across time and space. Soc. Forces $83,249-278$. Jacobs, David, Helms, Ronald, 1996. Towards a political model of incarceration. Am. J. Sociol. 102, $323-357$.

Jacobs, David, Helms, Ronald, 2001. Racial politics and redistribution: isolating the contingent influence of civil rights, riots, and crime on tax progressivity. Soc. Forces 80, 91-121.

Jacobs, David, Kent, Stephanie L., 2007. The determinants of executions since 1951: how politics, protests, public opinion, and social divisions shape capital punishment. Soc. Probl. 54, 297-318.

Jacobs, David, Qian, Zhenchao, Carmichael, Jason, Kent, Stephanie, 2007. Who survives on death row? an individual and contextual analysis. Am. Sociol. Rev.

\footnotetext{
${ }^{5}$ When we ran each law as a separate dependent variable, results from logistic analyses revealed that states with a history of discovered wrongful convictions are only more likely to pass laws that require compensation for the wrongfully convicted and not those laws aimed at preventing wrongful convictions. Similar to workers' compensation statutes, having a law that stipulates the exact compensation to which exonerees are entitled may limit the state's involvement with prolonged and expensive civil litigation initiated by each individual exoneree, so this finding perhaps reflects an administrative decision about efficiency more than a humanitarian effort to aid the wrongfully convicted.

${ }^{6}$ Gottschalk (2006) suggests that the death penalty abolitionist movement and some of the legislative reforms we study here could have an unintended effect on public opinion about punitive measures. She suggests that these movements, by promoting alternatives to the death penalty such as life in prison without parole (LWOP), and by creating a sense that the wrongful conviction laws work to make the criminal justice process fair, provide a false sense of public confidence in the criminal justice system, and encouraging other punitive tendencies (like LWOP) in place of the death penalty. While she does not make predictions about the innocence movement specifically, we agree that a trend in states adopting the laws we study here does not necessarily correspond to actual decreases in wrongful convictions. Legislative change represents only one tactic used by social movements.
} 
Jenness, Valerie, 1999. Managing differences and making legislation: social movements and the racialization, sexualization, and gendering of federal hate crime law in the U.S., 1985-1998. Soc. Probl. 46, 548-571.

Jones, Cynthia E., 2005. Evidence destroyed, innocence lost: the preservation of biological evidence under innocence protection statutes. Am. Crim. Law Rev. $42,1239-1270$.

Kane, Melinda D., 2003. Social movement policy success: decriminalizing state sodomy laws, 1969-1998. Mobilization 8 (3), 313-334.

Kassin, Saul M., Drizin, Steven A., Grisso, Thomas, Gudjonsson, Gisli H., Leo, Richard A., Redlich, Allison D., 2010. Police-induced confessions: risk factors and reccomendations. Law Hum Behav. 34, 3-38.

Keen, Bradley, Jacobs, David, 2009. Racial threat, partisan politics, and racial disparities in prison admissions: a panel analysis. Criminology 47, 209-238.

Kent, Stephanie L., Carmichael, Jason T., 2014. Racial residential segregation and social control: a panel study of the variation in police strength across U.S Cities, 1980-2010. Am. J. Crim. Just. 39 (2), 228-249.

Kent, Stephanie L., Jacobs, David, 2005. Minority threat and police strength from 1980 to 2000 : a fixed-effects analysis of nonlinear and interactive effects in large U.S cities. Criminology 43, $731-760$.

Leo, Richard A., 2005. Rethinking the study of miscarriages of justice: developing a criminology of wrongful conviction. J. Contemp. Crim. Justice 21 (3), 201-223.

Martin, Dianne L, 2001. Lessons about Justice from the "Laboratory" of wrongful convictions: tunnel vision, the construction of guilt and informer evidence. Univ. Missouri-Kansas City Law Rev. 70, 847.

McAdam, Douglas, 1999. Political Process and the Development of Black Insurgency, 1930-1970, second ed. University of Chicago Press, Chicago.

McCammon, Holly J., 2012. Explaining frame variation: moderate and more radical demands for women's citizenship in the U.S. women's jury movements. Soc. Prob1. 59, 43-69.

McMahon, Martha, 1995. Engendering Motherhood: Identity and Self-Transformation in Women's Lives. Guilford, New York.

Mumma, Christine C., 2004. The North Carolina actual innocence commission: uncommon perspectives joined by a common cause. Drake Law Rev. $52,647-$ 656.

Norris, Robert J., 2012. Assessing compensation statutes for the wrongly convicted. Crim. Just. Policy Rev. 23, 352-374.

Norris, Robert J., Bonventre, Catherine L., Redlich, Allison D., Acker, James R., 2011. Than that one innocent suffer: evaluating state safeguards against wrongful convictions. Albany Law Rev. 74 (3), 1301-1364.

Oliver, Willard M., 2003. The Law and Order Presidency. Prentice Hall, Upper Saddle River, NJ.

Owens, Michael Leo, Griffiths, Elizabeth, 2012. Uneven reparations for wrongful convictions: examining the state politics of statutory compensation legislation. Albany Law Rev. 75, 1283-1327.

Quillian, Lincoln, Pager, Devah, 2001. Black neighbors, higher crime? the role of racial stereotypes in evaluations of neighborhood crime. Am. J. Sociol. 107, 717-767.

Ramsey, Robert J., Frank, James, 2007. Wrongful conviction: perceptions of criminal justice professionals regarding the frequency of wrongful conviction and the extent of system error. Crime Delinquency 53 (3), 436-470.

Risinger, Michael R., 2007. Innocents convicted: an empirically justified factual wrongful conviction rate. J. Crim. Law Criminol. 97 (3), $761-806$.

Santoro, Wayne A., 2002. The civil rights movement's struggle for fair employment: a 'dramatic events-conventional politics' model. Soc. Forces 81 (1), $177-$ 206.

Scheck, Barry, Neufeld, Peter, Dwyer, Jim, 2000. Actual Innocence. Random House, New York.

Siegel, Andrew M., 2005. Moving down the wedge of injustice: a proposal for a third generation of wrongful convictions scholarship and advocacy. Am. Crim. Law Rev. 42, 1219-1237.

Soule, Sarah A., McAdam, Doug, McCarthy, John, Yang, Su, 1999. Protest events: cause or consequence of state action? The U.S. women's movement and federal congressional activities. Mobilization 4, 239-256

Stucky, Thomas D., Heimer, Karen, Lang, Joseph B., 2005. Partisan politics, electoral competition, and imprisonment. Criminology $43,211-248$.

Thomas, Clive S., Hrebenar, Ronald J., 2004. Interest groups in the states. In: Gray, Virginia, Hanson, Russell L. (Eds.), Politics in the American States: A Comparative Analysis. Sage Publications lnc., Thousand Oaks, CA.

Unnever, James D., Cullen, Francis T., 2010. The social sources of americans' punitiveness: a test of three competing models. Criminology 48 (1), 99-129. Walker, Jack L., 1991. Mobilizing Interest Groups in America: Patrons, Professions, and Social Movements. The University of Michigan Press, Ann Arbor, Ml. Weidner, Robert R., Frase, Richard S., 2003. Legal and extralegal determinants of intercounty differences in prison use. Crim. Just. Policy Rev. 14, $377-400$. Wells, Gary L., Olson, Elizabeth A., 2003. Eyewitness testimony. Annu. Rev. Psychol. 54, 277-295.

Western, Bruce, 2006. Punishment and Inequality in America. Russell Sage Foundation, New York.

Whitman, James Q., 2003. Harsh Justice: Criminal Punishment and the Widening Divide between America and Europe. Oxford University Press, New York. Zalman, Marvin, Larson, Matthew J., Smith, Brad W., 2012. Citizens' attitudes toward wrongful convictions. Crim. Just. Rev. 37 (1), 51-69.

\section{Post-print standardized by MSL Academic Endeavors, the imprint of the Michael Schwarts Library at Cleveland State University, 2018}

